\title{
ANALISA TERHADAP LOYALITAS PELANGGAN PORTABLE GRILL \& SHABU TANGERANG
}

\author{
Devi Rofianingsih \\ Sekolah Tinggi Ilmu Ekonomi Bisnis Indonesia, Jakarta Selatan \\ e-mail: devirofianingsih@gmail.com \\ Haryadi Sarjono \\ Binus Business School, Binus University, Jakarta Barat \\ e-mail: haryadi_s@binus.edu
}

\begin{abstract}
The purpose of this research is to determine the effect of service quality and price on customer satisfaction and impact on customer loyalty of Portable Grill \& Shabu Tangerang. This research using Structural Equation Modeling method with LISREL 8.8 program. The sample of this research is 224 respondent. This result showed that there is an influence of service quality on customer satisfaction with coefficient of 0,78 , there isn't significant influence of price on customer satisfaction with coefficient of 0,099, there isn't influence of service quality on customer loyalty with coefficient of -0,14, there is an influence of price on customer loyalty with coefficient of 0,44, there isn't significant influence of sevice quality on customer loyalty by using customer satisfaction with coefficient of 0,0082 and there is an influence of price on customer loyalty by using customer satisfaction with coefficient of 0,46 .
\end{abstract}

\begin{abstract}
ABSTRAK
Tujuan dari penelitian ini adalah untuk mengetahui pengaruh kualitas pelayanan dan harga terhadap kepuasan konsumen dan berpengaruh terhadap loyalitas konsumen pada Portable Grill \& Shabu Tangerang. Penelitian ini menggunakan metode Structural Equation Modeling dengan program LISREL 8.8. Sampel penelitian ini adalah 224 responden. Hasil penelitian ini menunjukkan bahwa terdapat pengaruh kualitas pelayanan terhadap kepuasan konsumen dengan koefisien 0,78 , tidak terdapat pengaruh harga yang signifikan terhadap kepuasan konsumen dengan koefisien 0,099, tidak terdapat pengaruh kualitas pelayanan terhadap loyalitas konsumen dengan koefisien sebesar dari -0,14 terdapat pengaruh harga terhadap loyalitas pelanggan dengan koefisien 0,44 , tidak terdapat pengaruh yang signifikan kualitas layanan terhadap loyalitas pelanggan dengan menggunakan kepuasan pelanggan dengan koefisien 0,0082 dan terdapat pengaruh antara harga terhadap loyalitas pelanggan dengan menggunakan kepuasan pelanggan dengan koefisien 0,46 .
\end{abstract}

Kata Kunci: Kualitas Layanan, Harga, Kepuasan Pelanggan, Loyalitas Pelanggan, LISREL

\section{PENDAHULUAN}

Indonesia merupakan negara kepulauan terbesar di dunia. Jumlah penduduk Indonesia pun menempati urutan terbesar keempat. Dengan adanya pertambahan penduduk yang diiringi dengan perubahan jaman dan lingkungan, masyarakat juga mengalami peningkatan kebutuhan baik dalam sektor makanan maupun sektor non-makanan. Bisnis kuliner merupakan bisnis yang sedang berkembang di Indonesia pada saat ini. Munculnya variasi makanan yang unik, adanya wisata kuliner, dan tren kuliner sebagai gaya hidup masyarakat, 


\section{Buletin Ekonomi}

adalah suatu bukti bahwa bisnis ini berkembang dengan pesat. Banyaknya rumah makan (restoran) yang muncul sebagai suatu usaha penyedia jasa makanan dan minuman semakin memperkuat bahwa bisnis kuliner ini semakin masif.

Tabel 1. Presentase Rata-rata Pengeluaran per Kapita per-bulan menurut Kelompok Barang, tahun 2015 dan 2016

\begin{tabular}{l|r|r|r|r|r|r}
\hline \multirow{2}{*}{ Kelompok Barang } & \multicolumn{3}{|c|}{$\mathbf{2 0 1 5}$} & \multicolumn{3}{c}{$\mathbf{2 0 1 6}$} \\
\cline { 2 - 8 } & Kota & Desa & $\begin{array}{c}\text { Kota+ } \\
\text { Desa }\end{array}$ & Kota & Desa & $\begin{array}{c}\text { Kota+ } \\
\text { Desa }\end{array}$ \\
\hline Makanan/Food & 5.47 & 11,41 & 7,70 & 4,98 & 10,04 & 6,82 \\
\hline Padi-padian Organic & 0,36 & 0,78 & 0,51 & 0,38 & 0,88 & 0,53 \\
\hline Umbi-umbian & 3,10 & 4,66 & 3,69 & 3,06 & 2,20 & 3,55 \\
\hline Ikan/Udang/Cumi/ Kerang & 2,19 & 1,89 & 2,08 & 2,30 & 1,94 & 2,17 \\
\hline Daging & 3,17 & 2,89 & 3,06 & 3,06 & 2,79 & 2,96 \\
\hline Telor dan Susu & 2,55 & 4,14 & 3,15 & 3,01 & 4,75 & 3,65 \\
\hline Sayur-sayuran & 1,00 & 1,40 & 1,15 & 0,97 & 1,30 & 1,09 \\
\hline Kacang-kacangan & 2,27 & 2,42 & 2,32 & 2,05 & 2,02 & 2,04 \\
\hline Buah-buahan & 1,16 & 2,10 & 1,51 & 1,06 & 1,84 & 1,34 \\
\hline Minyak dan Kelapa & 1,30 & 2,35 & 1,70 & 1,34 & 2,30 & 1,69 \\
\hline Bahan Minuman & 0,77 & 1,28 & 0,96 & 0,79 & 1,28 & 0,97 \\
\hline Bumbu-bumbuan & 13,53 & 11,21 & 12,66 & 15,22 & 12,27 & 14,41 \\
\hline $\begin{array}{l}\text { Makanan dan Minuman } \\
\text { Jadi }\end{array}$ & 4,79 & 7,85 & 5,94 & 5,45 & 8,91 & 6,72 \\
\hline Rokok Total & $\mathbf{4 2 , 5 5}$ & $\mathbf{5 5 , 6 3}$ & $\mathbf{4 7 , 4 7}$ & $\mathbf{4 4 , 5 7}$ & $\mathbf{5 5 , 8 3}$ & $\mathbf{4 8 , 6 8}$ \\
\hline \multicolumn{1}{|c|}{} & & & & \\
\hline
\end{tabular}

Sumber: Statistik Indonesia (2017)

Berdasarkan data Badan Pusat Statistik 2017, pengeluaran pendapatan per kapita masyarakat di bidang makanan tahun 2016 lebih tinggi sebesar 48,68\% daripada pengeluaran tahun 2015 yang hanya mencapai $47,47 \%$. Berikut alasan peneliti memilih jasa rumah makan:

1. Subsektor kuliner berkontribusi $41,4 \%$ dari total kontribusi perekonomian kreatif Rp 922 triliun pada 2016. Jumlah tersebut merupakan jumlah tertinggi dibandingkan 16 subsektor lain di Bekraf RI. (www.kompas.com)

2. Pada tahun 2013, tercatat kunjungan orang Indonesia ke restoran mencapai 380 juta kali dan menghabiskan total USD 1,5 miliar. (www.tribunnews.com)

3. Pada tahun 2017, kuliner menyumbang 32\% terhadap PDB ekonomi kreatif atau sekitar 220 triliun dari total ekonomi kreatif sebesar 700 triliun. (www.merdeka.com)

Menurut BPS, jumlah restoran untuk wilayah Banten tahun 2012 adalah sebesar 23,26\%, sedangkan pada tahun 2015 presentase restoran di daerah ini menjadi 29,41\%. Berdasarkan data tersebut, pertumbuhan restoran di daerah Banten cukup baik, yaitu $6,15 \%$ dalam kurun waktu tiga tahun. Berikut alasan peneliti memilih kota Tangerang sebagai tempat penelitian:

1. Pada tahun 2017, Tangerang telah menyerap 20.000 tenaga kerja dari 1.338 proyek kegiatan. (www.tangerangnews.com)

2. Dalam kurun waktu 12 tahun, Kota Administratif Tangerang memperlihatkan perkembangan dan pertumbuhan yang sangat pesat di berbagai bidang antara lain dalam penyelenggaraan pemerintah, pelaksanaan pembangunan dan pembinaan kemasyarakatan. Dinamika kehidupan perekonomian kota tersebut ditandai dengan berkembangnya berbagai usaha dan perdagangan serta pertumbuhan jumlah penduduk 


\section{Buletin Ekonomi}

yang mencapai 921.848 jiwa, laju pertumbuhan mencapai 8,27\% diakibatkan oleh derasnya arus urbanisasi yang mempengaruhi kehidupan sosial-politik, budaya dan perekonomian masyarakat. (www.tangerangkota.go.id)

3. Angka pertumbuhan ekonomi di Kota Tangerang lebih tinggi dari nasional yakni sebesar 5,30 persen dibandingkan dengan pertumbuhan ekonomi nasional yang hanya sebesar 5,02 persen. (www.tangerangkota.go.id)

Kepuasan dan ketidakpuasan pelanggan dapat mempengaruhi pola perilaku selannjutnya. Berikut data keluhan konsumen Portable Grill \& Shabu Tangerang (Manajemen Portable Grill \& Shabu, 2018):

1. Lamanya penyajian makanan saat jam ramai

2. Sepinya pengunjung saat weekdays, dikarenakan market hidup pada weekend

3. Sulitnya memanggil pelayan saat jam ramai

4. Makanan yang di pesan tidak sesuai dengan makanan yang disajikan

5. Terkadang terjadi kesalahan input pada sistem

Pelanggan yang puas cenderung mejadi loyal terhadap suatu produk atau jasa. Loyalitas pelanggan merupakan suatu variabel endogen yang disebabkan oleh kombinasi dari kepuasan sehingga loyalitas tidak lain adalah fungsi dari kepuasan pelanggan.

\section{Gambar 1. Data Pelanggan Portable Grill \& Shabu Tangerang Agustus 2017 - Maret 2018}

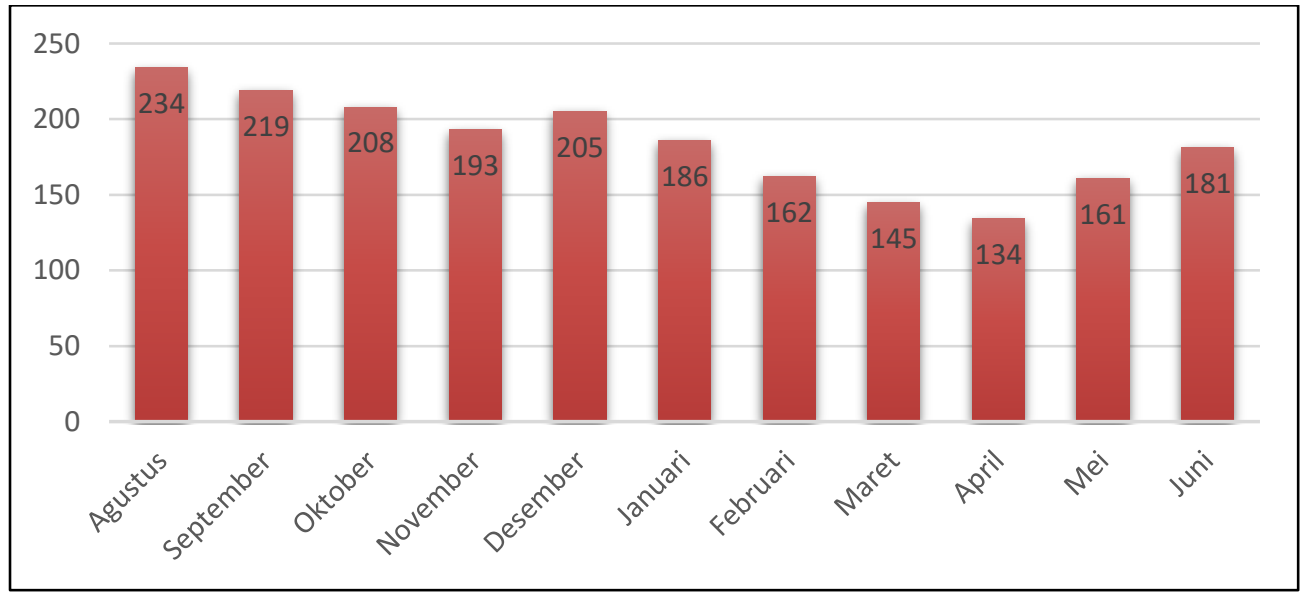

Sumber: Data sekunder yang diolah peneliti, (2018)

Berdasarkan Gambar diatas, terlihat bahwa jumlah pelanggan Portable mengalami penurunan kecuali pada bulan Desember, Mei dan Juni. Penurunan tertinggi terjadi pada bulan Februari sebesar 24 orang sedangkan kenaikan pelanggan cukup signifikan terjadi pada bulan Juni sebanyak 27 orang. Dengan adanya kekurangan-kekurangan yang terjadi pada Restoran Portable Grill \& Shabu tersebut serta untuk mempermudah penelitian ini, kami menggunakan metode SEM dengan kelebihan sebagai berikut:

Berdasarkan tabel diatas peneliti menggunakan metode SEM dengan kelebihan sebagai berikut:

1. SEM mampu menguji model struktural sekaligus model pengukuran dibandingkan dengan Analisis Jalur dan Analisis Regresi, hanya mampu menguji model struktural. (Sarjono dan Julianita 2015:41)

2. SEM mampu menguji kesalahan pengukuran sekaligus kesalahan struktural dibandingkan dengan Analisis Jalur dan Analisis Regresi yang hanya mampu menguji kesalahan struktural. (Sarjono dan Julianita 2015:41) 


\section{Buletin Ekonomi}

Berdasarkan latar belakang masalah diatas, maka rumusan masalah dalam penelitian ini adalah:

1. Seberapa besar pengaruh Kualitas Pelayanan dan Harga terhadap Kepuasan Pelanggan terhadap Loyalitas Pelanggan Restoran Portable Grill \& Shabu Tangerang, secara parsial?

2. Seberapa besar pengaruh Kualitas Pelayanan dan Harga terhadap Kepuasan Pelanggan terhadap Loyalitas Pelanggan Restoran Portable Grill \& Shabu Tangerang, secara simultan?

Pengertian Kualitas Pelayanan

Menurut ISO 9000 dalam Lupiyoadi (2014) kualitas adalah derajat yang dicapai oleh karakteristik yang inheren dalam rangka memenuhi kebutuhan atau harapan yang biasanya tersirat atau wajib. Menurut Kotler dan Keller dalam Umar (2014) pelayanan merupakan semua tindakan atau kinerja yang ditawarkan oleh satu pihak kepada pihak lain, umumnya tidak berwujud dan tidak menghasilkan kepemilikan dalam bentuk apapun. Kualitas jasa adalah tingkat keunggulan (excellence) yang diharapkan dan cara pengendalian atas keunggulan tersebut yang bertujuan untuk memenuhi keinginan pelanggan (Wyckof dalam Tjiptono, 2014). Menurut Parasuraman et al. Dalam Lupiyoadi (2014) kualitas pelayanan adalah seberapa jauh perbedaan antara kenyataan dan harapan pelanggan atas layanan yang diterima. Menurut Zeithaml dalam Sasongko (2014) terdapat lima dimensi model Servqual (Service Quality):

1. Tangible (Keberwujudan), adalah penampilan fisik dari perusahaan seperti fasilitas, penampilan personil dan komunikasi.

2. Responsiveness (Ketanggapan), adalah kemauan untuk membantu dan memberikan pelayanan yang cepat dan tepat kepada pelanggan dengan penyampaian informasi yang jelas.

3. Reliability (Kehandalan), adalah kemampuan perusahaan dalam memberikan pelayanan sesuai yang dijanjikan secara akurat dan terpercaya.

4. Assurance (Jaminan dan Kepastian), adalah pengetahuan, kesopansantunan dan kemampuan pegawai perusahaan dalam menumbuhkan rasa kepercayaan pelanggan kepada perusahaan.

5. Emphaty (Empati), adalah memberikan perhatian yang tulus dan bersifat individu atau pribadi yang diberikan kepada pelanggan disertai upaya untuk memahami keinginan konsumen.

Pengertian Harga

Harga merupakan sejumlah uang yang ditagihkan atas suatu produk atau jasa atau dengan kata lain harga adalah jumlah nilai yang ditukarkan oleh pelanggan untuk memperoleh manfaat dari memiliki atau menggunakan suatu produk atau jasa (Kotler dan Amstrong dalam Habibah dan Sumiati, 2016). Harga merupakan sejumlah uang yang dibutuhkan untuk mendapatkan berberapa produk atau kombinasi antara barang dan jasa (Sunyoto, 2012). Dari penelitian yang dilakukan oleh Djati dan Darmawan dalam Nugroho (2015) disampaikan bahwa dimensi harga terdiri dari:

1. Harga perkiraan, yaitu harga yang ditawarkan tidak berbeda jauh dengan perkiraan pelanggan sebelumnya.

2. Kesesuaian harga, yaitu harga yang ditawarkan perusahaan sesuai dengan kualitas produk layanan yang ditawarkan.

3. Kewajaran harga, yaitu harga yang ditawarkan tidak berbeda jauh dari pesaing.

Pengertian Kepuasan Pelanggan

Menurut Sudaryono (2016) kepuasan merupakan hasil dari penilaian konsumen bahwa suatu produk atau pelayanan jasa mampu memberikan tingkat kenikmatan dimana tingkat 


\section{Buletin Ekonomi}

pemenuhan ini bisa lebih atau kurang. Menurut Webster's 1928 Dictionary dalam Lupiyoadi (2014) pelanggan ialah seseorang yang beberapa kali datang ke tempat yang sama untuk membeli suatu barang atau peralatan atau untuk memenuhi apa yang ia inginkan. Kepuasan pelanggan menurut Kotler dalam Sugiarman et al. (2015) yaitu suatu tingkat keadaan yang dirasakan seseorang dan merupakan hasil dari perbandingan antara penampilan (outcome) produk atau jasa tersebut dengan harapan yang dimiliki pelanggan. Menurut Mowen Tjiptono (2014) kepuasan pelanggan adalah sikap keseluruhan terhadap barang atau jasa setelah perolehan (acquisition) dan pemakaiannya. Dengan kata lain, kepuasan pelanggan adalah sebuah penilaian evaluatif purna beli yang dihasilkan dari seleksi pembelian spesifik. Menurut Fonell dalam Shelfy (2014) dimensi kepuasan pelanggan terdiri dari tiga hal, yaitu:

1. Kepuasan general atau keseluruhan (overall satisfaction)

2. Konfirmasi harapan (Confirmation of expectation), merupakan tingkat kesesuaian antara kinerja dengan ekspektasi

3. Perbandingan situasi ideal (comparison to ideal)

Pengertian Loyalitas Pelanggan

Loyalitas adalah suatu bentuk yang melukiskan kesediaan seorang pelanggan untuk terus berlangganan pada perusahaan dalam jangka waktu yang panjang dengan membeli dan menggunakan barang serta layanan secara berulang-ulang, lebih baik lagi secara eksklusif dan suka rela merekomendasikan produk kepada teman-teman, rekan dan keluarganya (Sasongko, 2014). Loyalitas pelanggan adalah sebuah komitmen pelanggan terhadap suatu merek, toko atau pemasok, melalui sikap yang sangat positif dan tercermin dengan pembelian ulang yang konsisten (Sheth dan Mittal dalam Tjiptono, 2014). Menurut Zeithaml dalam Shelfy (2014) terdapat empat dimensi loyalitas pelanggan, yaitu:

1. Word of Mouth Communication, merupakan proses komunikasi dari mulut ke mulut baik secara individu maupun kelompok yang memberi rekomendasi baik mengenai suatu produk dengan tujuan memberikan informasi secara personal.

2. Intensitas pembelian (Purchase Intention), yaitu keinginan untuk membeli kembali suatu produk.

3. Price Sensitivity, yaitu kepekaan konsumen terhadap kategori produk tertentu yang mampu merangsang atau mendorong konsumen untuk membelinya.

4. Complaining behavior, yaitu tindakan konsumen mengomunikasikan hal negatif mengenai suatu produk kepada pemasok atau pihak yang bersangkutan.

\section{KERANGKA PIKIR}

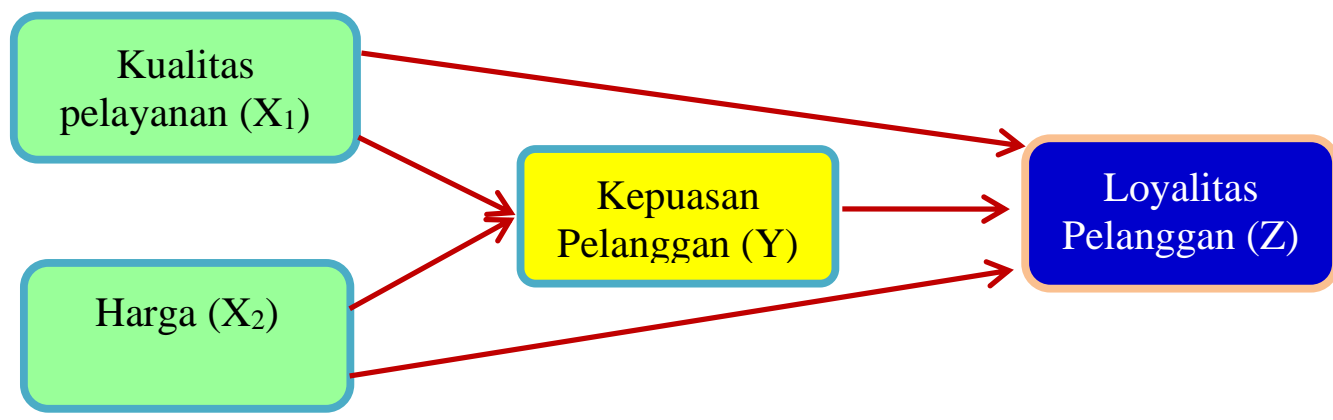

Sumber: diolah peneliti (2018)

Gambar 2. Model Penelitian 


\section{Buletin Ekonomi}

\section{METODE}

Menurut Sugiyono (2016) metode penelitian merupakan cara ilmiah yang digunakan untuk mendapatkan data dengan tujuan dan kegunaan tertentu. Metode pengolahan data yang akan digunakan dalam penelitian ini adalah metode SEM (Structural Equation Modeling). Menurut Hox dan Bechger dalam Sarjono dan Julianita (2015) SEM merupakan sebuah teknik analisis multivariat yang dikembangkan guna menutupi keterbatasan yang dimiliki oleh model analisis sebelumnya dan telah digunakan secara luas dalam penelitian statistik.

\section{Tempat dan Waktu Penelitian}

Tempat yang dijadikan obyek penelitian ini adalah Restoran Portable Grill \& Shabu, Jl. Raya Kelapa Gading Utara No.39 Pakulonan Bar Kelapa Dua Tangerang, Banten, 15810, Indonesia. Waktu penelitian ini yaitu dari bulan April- September 2018.

\section{Skala Pengukuran Variabel}

Model skala yang digunakan dalam penelitian ini adalah skala likert. Menurut Yamin (2014:1) skala likert merupakan skala yang paling populer dan mudah diimplementasikan dalam berbagai bidang penelitian terutama dalam bidang penelitian sosial. Penelitian ini tidak menggunakan 5 skala (tidak menggunakan nilai netral). Menurut Garland dalam Budiaji (2013), jumlah titik respon genap (4) lebih disarankan dari pada jumlah titik ganjil (5) sehingga bias sosial bisa dikurangi. Bias sosial yang dimaksud di atas adalah keinginan untuk menyenangkan perasaan peneliti agar dianggap sebagai penolong peneliti dengan bersedia menjadi responden. Responden akan cenderung memilih "netral" atau tidak memilih.

\section{Populasi dan Sampel}

Menurut Cooper dan Schindler (2017) populasi ialah total kumpulan elemen dimana kita ingin mengambil sejumlah kesimpulan. Menurut Sugiyono dalam Habibah dan Sumiati (2016) populasi merupakan wilayah generalisasi yang terdiri atas objek atau subjek yang memiliki kualitas dan karakteristik tertentu serta ditetapkan untuk dipelajari kemudian ditarik kesimpulannya. Menurut Nazir (2014) sampel merupakan kumpulan dari unit sampling. Jumlah Populasi dalam penelitian ini adalah 2.028 responden. Berdasarkan perhitungan menggunakan rumus Slovin, di dapat jumlah sampel sebanyak 224 responden.

\section{Teknik Pengumpulan dan Analisa Data}

Teknik pengumpulan data dalam penelitian ini menggunakan kuesioner dan kepustakaan. Menurut Sekaran dan Bougie (2017) kuesioner merupakan suatu daftar pertanyaan tertulis yang telah dirumuskan sebelumnya di mana responden akan memberi jawaban mereka, biasanya dalam bentuk alternatif yang didefiniskan dengan jelas. Studi kepustakaan dilakukan dengan cara mencari literatur yang berhubungan dengan penelitian, seperti buku, jurnal, majalah, koran, penelitian terdahulu, artikel, hasil survei yang dilakukan oleh lembaga survei dan berbagai dokumen yang berkaitan dengan teori-teori dan data tentang kulitas pelayanan, harga, kepuasan pelanggan dan loyalitas pelanggan.

\section{ANALISIS DAN PEMBAHASAN Validitas}

Validitas adalah kriteria utama keilmiahan suatu penelitian. Uji validitas digunakan untuk mengukur ketepatan dan kecermatan suatu item dalam mengukur apa yang diukur (Darmawan dan Wulandari, 2016). Suatu indikator dikatakan valid jika mempunyai standardized loading diatas 0,70. Pada riset pengembangan, standardized loading 0,50 sampai 0,60 masih dapat diterima (Ghozali dan Fuad, 2014). 


\section{Buletin Ekonomi}

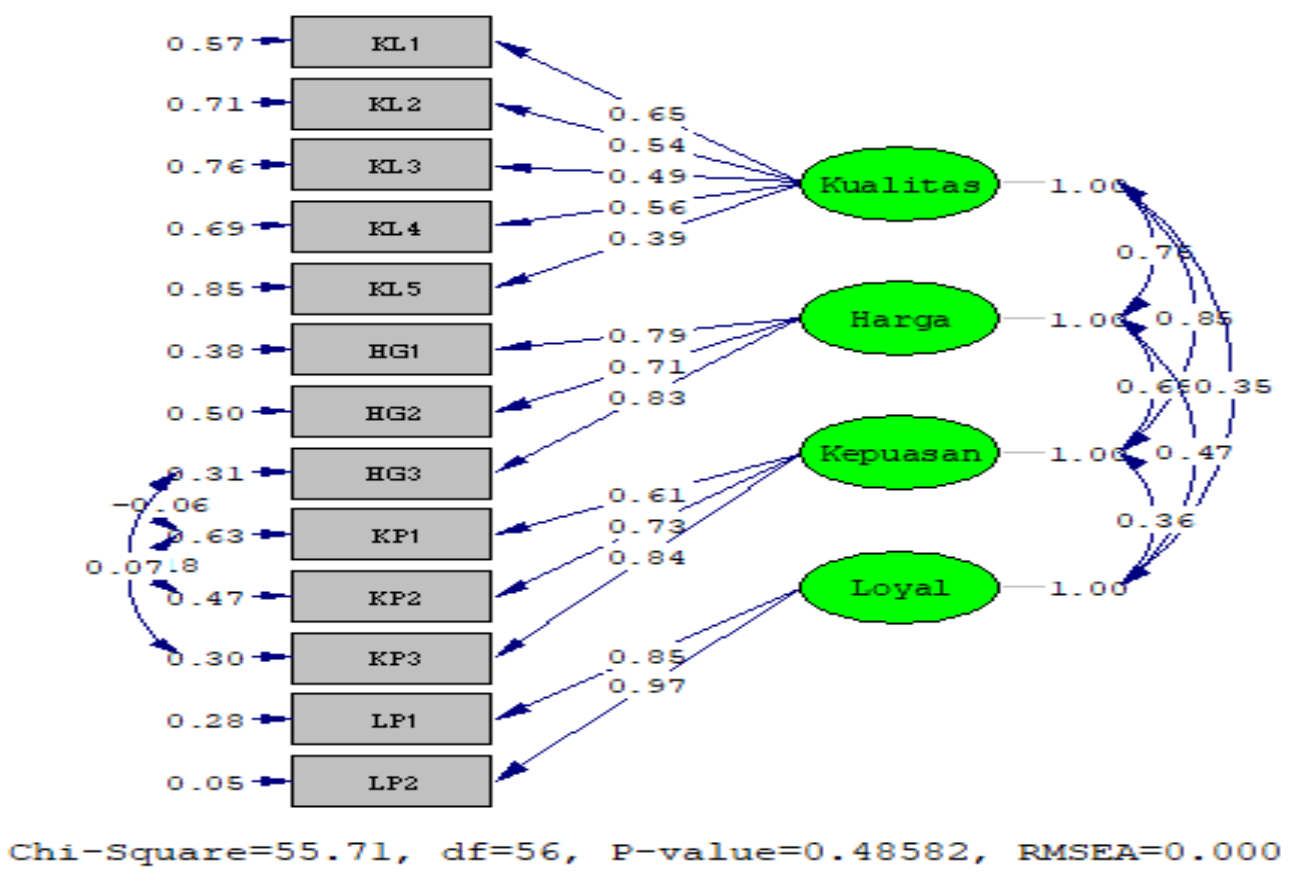

Sumber: Hasil olah data Lisrel 8.8, (2018)

Berdasarkan hasil uji valididtas tersebut, seluruh indikator dikatakan falid kecuali indikator KP3 dan KP5. Suatu indikator dikatakan valid jika memiliki nilai loading factor $\geq$ 0,5 . Indikator yang tidak valid $(<0,5)$ sebaiknya di buang dari model. Dari pernyataan tersebut maka indikator KL3 dan KL5 tidak dipakai dalam pengujian selanjutnya oleh peneliti.

\section{Reliabilitas}

Uji Reliabilitas digunakan untuk mengukur tingkat konsistensi variabel manifes dalam mengukur konstruk latennya (Sarjono dan Julianita, 2015). Nilai AVE diharapkan adalah > 0,5. Nilai AVE yang kurang dari 0,5 menunjukkan bahwa measurement error banyak berkontribusi kepada indikator daripada variabel laten (Ghozali dan Fuad, 2014).

Hasil Pengujian Model Fit

\begin{tabular}{l|l|c|c|c}
\hline $\begin{array}{c}\text { Fit } \\
\text { Measure }\end{array}$ & \multicolumn{1}{|c|}{ Good Fit } & Marginal Fit & $\begin{array}{c}\text { Hasil } \\
\text { Penelitian }\end{array}$ & $\begin{array}{c}\text { Tingkat } \\
\text { Kecocokan }\end{array}$ \\
\hline$\chi^{2} / \mathrm{df}$ & $0 \leq \chi^{2} \leq 2 d f$ & - & 0,899 & Acceptable Fit \\
\hline RMSEA & $\begin{array}{l}\text { RMSEA } \leq \\
\text { R }\end{array}$ & - & 0,00 & Close Fit \\
\hline GFI & GFI $\geq 0,9$ & $\begin{array}{c}0,8 \leq \mathrm{GFI} \leq \\
0,9\end{array}$ & 0,98 & Good Fit \\
\hline NFI & NFI $\geq 0,9$ & $\begin{array}{c}0,8 \leq \mathrm{NFI} \leq \\
0,9\end{array}$ & 0,98 & Good Fit \\
\hline CFI & CFI $\geq 0,9$ & $\begin{array}{c}0,8 \leq \mathrm{CFI} \leq \\
0,9\end{array}$ & 1,00 & Good Fit \\
\hline IFI & IFI $\geq 0,9$ & $0,8 \leq \mathrm{IFI} \leq 0,9$ & 1,00 & Good Fit \\
\hline RFI & RFI $\geq 0,9$ & $0,8 \leq \mathrm{RFI} \leq$ & 0,97 & Good Fit \\
\hline
\end{tabular}

Sumber: Hasil olah data Lisrel 8.8 (2018) 


\section{Buletin Ekonomi}

Berdasarkan data tersebut, model telah dikatakan good fit karena telah sesuai dengan kriteria yang telah di tetapkan.

\section{Parameter Standardized Loading Factor SEM}

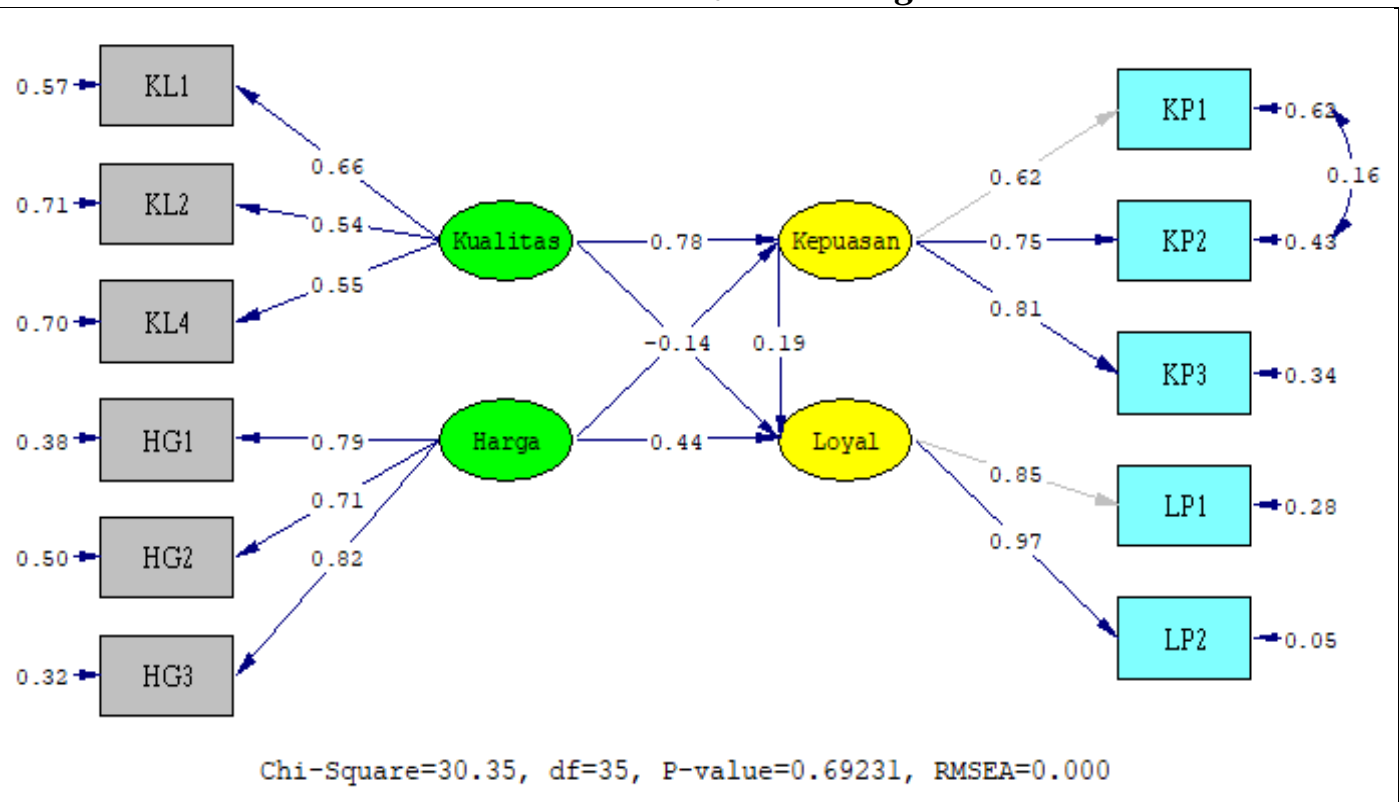

Sumber: Hasil olah data Lisrel 8.8, (2018)

Persamaan Struktural 1

$$
\begin{gathered}
\text { Kepuasan }=0.78^{*} \text { Kualitas }+0.099^{*} \text { Harga, Errorvar }=0.26, \mathrm{R}^{2}=0.74 \\
4.02^{(0.19)} 0.56^{(0.18)} \quad 2.46^{(0.11)}
\end{gathered}
$$

Sumber: Hasil olah data Lisrel 8.8 (2018)

Berdasarkan persamaan struktural pertama, diketahui bahwa terdapat pengaruh Kualitas Pelanggan terhadap Kepuasan Pelanggan dengan nilai koefisien sebesar 0,78 dan t-hitung 4,02 dengan t-tabel 1,97 (t-hitung > t-tabel) atau Ha diterima.

Berdasarkan persamaan struktural pertama, diketahui bahwa nilai koefisien variabel Harga adalah 0,099 terhadap variabel Kepuasan Pelanggan dan t-hitung sebesar 0,56 dengan t-tabel 1,97 (t-hitung < t-tabel). Hal tersebut menunjukkan bahwa pengaruh variabel Harga terhadap Kepuasan Pelanggan tidak signifikan atau Ha ditolak.

\section{Persamaan Struktural 2}

\begin{tabular}{|cccc|}
\hline \multicolumn{5}{c}{ Loyal $=0.19^{*}$ Kepuasan } & $-0.14^{*}$ Kualitas $+0.44^{*}$ Harga, Errorvar $=0.77, R^{2}=$ \\
& \multicolumn{4}{c}{$(0.24)$} & $(0.30)$ & $(0.15)$ & $(0.12)$ \\
0.78 & -0.47 & 3.03 & 6.58 \\
\hline
\end{tabular}

Sumber: Hasil olah data Lisrel 8.8 (2018) 


\section{Buletin Ekonomi}

Berdasarkan persamaan struktural kedua, diketahui bahwa terdapat pengaruh Kepuasan Pelanggan terhadap Loyalitas Pelanggan dengan nilai koefisien sebesar 0,19 serta t-hitung 0,78 dan t-tabel 1,97 (t-hitung < t-tabel). Hal tersebut menunjukkan bahwa pengaruh variabel Kepuasan Pelanggan terhadap Loyalitas Pelanggan tidak signifikan atau Ha ditolak.

Berdasarkan persamaan struktural kedua, diketahui bahwa nilai koefisien Kualitas Pelayanan terhadap Loyalitas Pelanggan adalah -0,14. Hal tersebut menunjukkan bahwa Kualitas Pelayanan tidak mempengaruhi Loyalitas Pelanggan dengan t-hitung -0,47 dan t-tabel 1,97 (thitung < t-tabel) atau Ha ditolak.

Berdasarkan persamaan struktural kedua, diketahui bahwa terdapat pengaruh variabel Harga terhadap Loyalitas Pelanggan dengan nilai koefisien sebesar 0,44 serta t-hitung 3,03 dan ttabel 1,97 (t-hitung > t-tabel) atau Ha diterima.

\section{IMPLIKASI APLIKATIF}

\section{Pengaruh Kualitas Pelayanan terhadap Kepuasan Pelanggan}

Hasil penelitian ini menunjukkan bahwa terdapat pengaruh antara Kualitas Pelayanan terhadap Kepuasan Pelanggan dengan nilai koefisien sebesar 0,78 dan t-hitung sebesar 4,02 atau Ha diterima. Hasil penelitian ini sesuai dengan penelitian yang dilakukan oleh Sasongko (2014) dengan objek Nokia Care Center wilayah Jakarta bahwa kualitas layanan berpengaruh terhadap kepuasan pelanggan dengan koefisien 0,432 dan t-hitung sebesar 5,727 (t-value > 1,96). Berdasarkan penelitian Nugroho (2015) kualitas pelayanan berpengaruh positif terhadap kepuasan pelanggan dengan nilai pearson correlation sebesar 0,74 dan t-value sebesar 7,16. Perbedaan hasil penelitian ini disebabkan oleh adanya perbedaan variabel dan jumlah sampel yang digunakan. Penelitian yang dilakukan oleh Sasongko menggunakan 200 sampel, Nugroho dengan 220 sampel dan penelitian ini menggunakan 224 sampel.

\section{Pengaruh Harga terhadap Kepuasan Pelanggan}

Hasil penelitian ini menunjukkan bahwa terdapat pengaruh antara Harga terhadap Kepuasan Pelanggan dengan nilai koefisien sebesar 0,099. Pengaruh Harga terhadap Kepuasan Pelanggan tidak signifikan karena memiliki nilai t-hitung sebesar 0,56 < ttabel atau Ha ditolak. Sementara dalam penelitian yang dilakukan oleh Simanjuntak dan Sitinjak (2016) hasil penelitian menunjukkan bahwa dampak harga terhadap ketidakpuasan konsumen tidak signifikan dan positif (menolak Ha) dengan nilai koefisien sebesar -0,25. Mengacu pada penelitian Simanjuntak dan Sitinjak, variabel penelitian ini merupakan kebalikan dari variabel ketidakpuasan. Perbedaan hasil penelitian disebabkan karena perbedaan jumlah kuesioner yang dibagikan oleh peneliti.

Menurut Simanjuntak dan Sitinjak, konsumen akan puas jika konsumen senang dengan kinerja atau hasil suatu produk sama dengan atau lebih dari harapannya. Walaupun harga tidak berpengaruh secara signifikan terhadap kepuasan pelanggan, namun variabel ini harus tetap diperhatikan. Pelanggan akan menilai baik buruknya suatu perusahaan termasuk dari harga yang ditawarkan.

\section{Pengaruh Kualitas Pelayanan terhadap Loyalitas Pelanggan}

Hasil penelitian ini menunjukkan bahwa Kualitas Pelayanan tidak memiliki pengaruh terhadap Loyalitas Pelanggan dengan nilai koefisien sebesar -0,14. Kualitas Pelayanan tidak memengaruhi Loyalitas Pelanggan dilihat dari nilai t-hitung yang hanya sebesar $0,47<$ t-tabel atau Ha ditolak. Hasil penelitian ini sesuai dengan penelitian yang dilakukan oleh Nurlitasari dan Syah (2016) bahwa kualitas pelayanan tidak berpengaruh langsung terhadap loyalitas pasien dengan nilai $\mathrm{t}=1,56(<1,96)$.

Disisi lain, hasil penelitian ini tidak mendukung penelitian yang dilakukan oleh Sasongko (2014) bahwa kualitas pelayanan berpengaruh terhadap loyalitas pelanggan 


\section{Buletin Ekonomi}

Nokia dengan koefisien jalur 0,185 dan t-value sebesar 2,478 ( $t$-value > 1,96) yang memberikan pengaruh sebesar $3,4 \%$ terhadap loyalitas pelanggan. Perbedaan hasil penelitian ini disebabkan oleh adanya perbedaan variabel dan jumlah sampel yang digunakan. Penelitian yang dilakukan oleh Nurlitasari dan Syah menggunakan 170 sampel, Sasongko dengan 200 sampel dan penelitian ini menggunakan 224 sampel.

\section{Pengaruh Harga terhadap Loyalitas Pelanggan}

Hasil penelitian ini menunjukkan bahwa terdapat pengaruh antara Harga terhadap Loyalitas Pelanggan dengan nilai koefisien sebesar 0,44 dan t-hitung sebesar 3,03 atau Ha diterima. Penelitian ini sesuai dengan penelitian yang dilakukan oleh Nugroho (2015) bahwa Harga berpengaruh signifikan terhadap Loyalitas Pelanggan dengan nilai koefisien 0,15 dan t-hitung sebesar 2,21. Pengaruh positif variabel Harga disebabkan karena adanya hubungan antara dimensi kesesuaian dengan dimensi pembelian ulang dalam variabel Loyalitas Pelangan. Perbedaan hasil penelitian ini disebabkan oleh adanya perbedaan variabel dan jumlah sampel yang digunakan. Penelitian yang dilakukan oleh Nugroho menggunakan 220 sampel, sedangkan penelitian ini menggunakan 224 sampel. Harga berpengaruh terhadap Loyalitas Pelanggan, maka perusahaan harus selalu mempertimbangkan faktor-faktor penentu harga yang akan menghasilkan bentuk loyalitas dari konsumen terhadap suatu produk.

\section{Pengaruh Kepuasan Pelanggan terhadap Loyalitas Pelanggan}

Hasil penelitian ini menunjukkan bahwa Kepuasan Pelanggan memiliki pengaruh terhadap Loyalitas Pelanggan dengan nilai koefisien sebesar 0,19. Pengaruh Kepuasan Pelanggan terhadap Loyalitas Pelanggan tidak signifikan karena memiliki nilai t-hitung sebesar 0,78 < t-tabel atau Ha ditolak. Hasil penelitian ini tidak sesuai dengan penelitian yang dilakukan oleh Nugroho (2015) bahwa terdapat hubungan positif antara kepuasan pelanggan dan loyalitas pelanggan dengan nilai pearson correlation sebesar 0,626 dan $t$ value sebesar 4,34. Hasil penelitian ini juga berbeda dengan hasil penelitian Sasongko (2014) yang menyatakan bahwa kepuasan pelanggan berpengaruh terhadap loyalitas pelanggan dengan $t$-value 5,579 lebih besar dari t-tabel 1,96 dan memberikan pengaruh langsung sebesar $19,5 \%$ terhadap loyalitas pelanggan. Perbedaan hasil penelitian ini disebabkan oleh adanya perbedaan variabel dan jumlah sampel yang digunakan.

6. Pengaruh Kualitas Pelayanan terhadap Loyalitas Pelanggan Melalui

\section{Kepuasan Pelanggan}

Hasil penelitian ini menunjukkan bahwa Kualitas Pelayanan mempunyai pengaruh positif terhadap Loyalitas Pelanggan melalui variabel perantara Kepuasan Pelanggan dengan nilai koefisien 0,0082. Pengaruh tersebut tidak signifikan karena memiliki nilai thitung 0,003 (< t-tabel) atau Ha ditolak. Kualitas pelayanan tidak mempengaruhi loyalitas secara langsung, melainkan menggunakan perantara kepuasan pelanggan.

Pengaruh kualitas pelayanan terhadap kepuasan pelanggan secara langsung menunjukkan hasil yang positif, dengan demikian pengaruh kualitas pelayanan terhadap loyalitas pelanggan melalui kepuasan pelanggan akan memberikan hasil yang positif pula. Hasil penelitian ini sesuai dengan penelitian yang dilakukan oleh Nugroho (2015) bahwa kualitas pelayanan memiliki pengaruh positif terhadap loyalitas pelanggan namun tidak signifikan dengan nilai koefisien 0,14 dan t-hitung 1,18. Dalam penelitian Nugroho juga diketahui bahwa kualitas pelayanan memiliki pengaruh positif terhadap kepuasan pelanggan yang kemudian akan memberi dampak positif pula terhadap loyalitas pelanggan. Perbedaan hasil penelitian ini disebabkan oleh adanya perbedaan variabel dan jumlah sampel yang digunakan. 


\section{Buletin Ekonomi}

\section{Pengaruh Harga terhadap Loyalitas Pelanggan melalui Kepuasan Pelanggan}

Hasil penelitian ini menunjukkan bahwa Harga mempunyai pengaruh positif terhadap Loyalitas Pelanggan melalui variabel perantara Kepuasan Pelanggan dengan nilai koefisien 0,46 dan nilai t-hitung 3,04 (> t-tabel) atau Ha diterima. Hasil penelitian ini sesuai dengan penelitian yang dilakukan oleh Nugroho (2015) bahwa Harga mempengaruhi Loyalitas Pelanggan dengan nilai koefisien sebesar 0,15 dan t-hitung sebesar 2,21. Harga juga berpengaruh positif terhadap kepuasan pelanggan walaupun tidak signifikan dengan t-hitung sebesar 1,02. Perbedaan hasil penelitian ini disebabkan karena perbedaan variabel dan jumlah sampel penelitian

Menurut Sasongko (2014) Pelanggan yang loyal adalah aset yang sangat berharga bagi perusahaan. Untuk mendapatkan pelanggan yang loyal, perusahaan harus mampu memberikan penawaran produk atau jasa dengan kualitas yang baik dan mengikuti perkembangan jaman agar calon konsumen tertarik untuk melakukan pembelian. Jadi, perusahaan dikatakan baik jika dapat mempertahankan tingkat loyalitas pelanggannya dengan terus memperbaiki faktor-faktor penyebab ketidakpuasan pelanggan dan memperoleh laba melebihi target yang telah ditetapkan.

\section{KESIMPULAN DAN SARAN}

Berdasarkan hasil penelitian, dapat ditarik beberapa simpulan sebagai berikut:

1. Kualitas Pelayanan $\left(\mathrm{X}_{1}\right)$ memiliki pengaruh positip terhadap Kepuasan Pelanggan (Y)

2. Harga $\left(\mathrm{X}_{2}\right)$ memiliki pengaruh positip terhadap Kepuasan Pelanggan (Y)

3. Kualitas Pelayanan $\left(\mathrm{X}_{1}\right)$ memiliki pengaruh negatif terhadap Loyalitas Pelanggan $(\mathrm{Z})$

4. Harga $\left(\mathrm{X}_{2}\right)$ memiliki pengaruh positip terhadap Loyalitas Pelanggan $(\mathrm{Z})$

5. Kepuasan Pelanggan (Y) memiliki pengaruh yang tidak signifikan terhadap Loyalitas Pelanggan (Z)

6. Kualitas Pelayanan $\left(\mathrm{X}_{1}\right)$ memiliki pengaruh yang tidak signifikan terhadap Loyalitas Pelanggan (Z) melalui Kepuasan Pelanggan (Y)

7. Harga $\left(\mathrm{X}_{2}\right)$ memiliki pengaruh terhadap Loyalitas Pelanggan $(\mathrm{Z})$ melalui Kepuasan Pelanggan (Y)

Berdasarkan hasil penelitian dan simpulan diatas, berikut beberapa saran yang penulis sampaikan dan diharapkan dapat membantu pihak manajemen dalam mengambil keputusan, yaitu:

1. Selain rasa, fasilitas dan kecakapan karyawan juga mempengaruhi kepuasan pelanggan. Pelanggan akan merasa puas jika pelayanan yang di terima (baik dari segi produk, fasilitas maupun pelayanan) sesuai dengan harapan pelanggan, oleh sebab itu, fasilitas dan pelayanan terhadap juga perlu diperhatikan.

2. Harga merupakan faktor yang sangat penting bagi suatu usaha. Harga adalah satu-satunya unsur bauran pemasaran yang dapat menghasilkan pendapatan organisasi. Pemilihan strategi penetapan harga juga harus diperhatikan perusahaan karena berkaitan dengan permintaan dan laba yang akan dihasilkan.

3. Walaupun harga yang menjadi prioritas penilaian loyalitas, perusahaan harus tetap memperhatikan kualitas pelayanan. Pemberian pelayanan purna beli mungkin dapat diterapkan untuk membentuk suatu loyalitas.

4. Harga menjadi pokok penilaian untuk loyalitas pelanggan. Seorang konsumen akan membeli kembali jika produk yang didapatkan baik dan harga produk tersebut sesuai. Perusahaan dapat memberikan penawaran-penawaran menarik seperti pemberian voucher untuk pembelian tertentu, diskon dan promo menarik lainnya agar pelanggan lebih tertarik untuk kembali. 


\section{Buletin Ekonomi}

5. Pada dasarnya pelanggan yang puas terbagi menjadi dua, yaitu pelanggan yang puas namun belum tentu kembali karena dari wilayah yang berbeda (hanya mencoba atau ingin tahu) dan pelanggan yang puas serta memutuskan untuk menjadi pelanggan tetap. Seperti yang telah dijelaskan sebelumnya bahwa kepuasan pelanggan sendiri dipengaruhi oleh beberapa faktor, begitu pula loyalitas. Peningkatan fakor pendukung kepuasan dapat menjadi alternatif perusahaan untuk meningkatkan loyalitas tersebut.

6. Mengingat bahwa pengaruh kualitas pelayanan terhadap kepuasan pelanggan cukup tinggi, hal tersebut dapat dijadikan acuan peningkatan loyalitas pelanggan. Pengadaan training bagi karyawan untuk peningkatan SDM dan pemenuhan hak-hak karyawan (seperti pemberian bonus dan rekreasi bersama) mungkin dapat mempengaruhi kinerja karyawan yang akan meningkatkan kualitas pelayanan. Kualitas yang meningkat akan meningkatkan kepuasan pelanggan dan apabila nilai kepuasan meningkat maka kemungkinan besar pelanggan akan loyal terhadap perusahaan. Bagi loyalitas pelanggan, harga lebih berpengaruh daripada kualitas pelayanan. Pelanggan puas dan harga yang sesuai akan membuat pelanggan kembali.

Meskipun bukan poin utama penelitian, harga merupakan hal yang penting bagi setiap usaha. Harga dapat mempengaruhi posisi persaingan dan pangsa pasar. Perusahaan hendaknya mempertimbangkan aspek lain dalam penetapan harga jual produk seperti daya beli konsumen dan memantau harga pesaing untuk antisipasi beralihnya konsumen karena perbedaan yang sangat signifikan.

\section{DAFTAR PUSTAKA}

Cooper, Donald R. 2017. Metode Penelitian Bisnis. Salemba Empat, Jakarta.

Darmawan, Ahmad Hendra dan Wulandari, Dewi Ayu Nur. 2016. Dampak Peningkatan Jaringan 3G PT Indosat terhadap Kepuasan Pelanggan di Jabodetabek dengan Metode Structural Equation Modeling (SEM). Jurnal Pilar Nusa Mandiri 12 (2): 219-226.

Ferdinand, Agusty. 2014. Metode Penelitian Manajemen. Seri Pustaka Kunci, Semarang.

Feriyansyah, Ahmad. 2016. Pengaruh Bauran Pemasaran dan Kualitas Pelayanan terhadap Loyalitas Merek. Jurnal Ekonomika 6 (2): 85-97.

Ghozali, Imam dan Fuad. 2014. Structural Equation Modeling Teori, Konsep dan Aplikasi dengan Program LISREL 9.10. Badan Penerbit Universitas Diponegoro, Semarang.

Habibah, Ummu dan Sumiati. 2016. Pengaruh Kualitas Produk dan Harga terhadap Keputusan Pembelian Produk Kosmetik Wardah di Kota Bangkalan Madura. Jurnal Ekonomi dan Bisnis 1 (1): 31-47.

Indah R, Shelfy. 2014. Analisis Pengaruh Kualitas Pelayanan terhadap Kepuasan Penyewa dalam Upaya Meningkatkan Loyalitas Penyewa. Jurnal MIX 4 (1): 123-134.

Latan, Hengky. 2013. Structural Equation Modeling. Alfabeta, Bandung.

Lupiyoadi, Rambat. 2014. Manajemen Pemasaran Jasa. Salemba Empat, Jakarta. 


\section{Buletin Ekonomi}

Lupiyoadi, Rambat dan Ikhsan, Ridho Bramulya. 2015. Metode Riset Bisnis. Salemba Empat, Jakarta.

Nazir, Moh. 2014. Metode Penelitian. Ghalia Indonesia, Bogor.

Nugroho, Dwi Mulyono. 2015. Pengaruh Kualitas Pelayanan, Kualitas Produk Layanan, dan Harga Produk Layanan terhadap Kepuasan Pelanggan serta Dampaknya terhadap Loyalitas Pelanggan Prabayar Telkomsel. Jurnal OE 7 (2): 158-174.

Nurlitasari, Lili dan Syah, Tantri Yanuar R. 2016. Pengaruh Kualitas Layanan terhadap Kepuasan dan Loyalitas (Kasus: Rumah Sakit Medika Permata Hijau Jakarta Barat). Media Studi Ekonomi 19 (1): 95-110.

Prihanto, Agus. 2013. Kepuasan dan Loyalitas Konsumen Korporat untuk Acara Mice terhadap Kualitas Pelayanan Hotel HSTH. Jurnal Manajemen dan Kewirausahaan 15 (2): 165-177.

Sadika, Rengky Glorius. 2015. Pengaruh Kualitas Produk terhadap Loyalitas Melalui Kepuasan Konsumen. Jurnal Riset Manajemen dan Akuntansi 3 (2): 122-133.

Sarjono, Haryadi dan Julianita, Winda. 2015. Structural Equation Modeling. Salemba Empat, Jakarta.

Sasongko, Gerry. 2014. Analisis Pengaruh Citra Merek dan Kualitas Layanan terhadap Loyalitas Pelanggan Melalui Kepuasan Pelanggan. Jurnal MIX 4 (2): 270-285.

Selang, Christian A.D. 2013. Bauran Pemasaran (Marketing Mix) Pengaruhnya terhadap Loyalitas Konsumen Pada Fresh Mart Bahu Mall Manado. Jurnal EMBA 1 (3): 71-80.

Sekaran, Uma dan Bougie, Roger. 2017. Metode Penelitian Untuk Bisnis. Salemba Empat, Jakarta.

Simanjuntak, Juara dan Sitinjak, Imelda. 2016. Dampak Harga Produk, Kualitas Produk, Kualitas Pelayanan dan Keberhasilan Pasar terhadap Ketidakpuasan Berbelanja di Pasar Tradisional dan Perpindahan Berbelanja dari Pasar Tradisional ke Pasar Modern. Wahana Inovasi 5 (1): 150-162.

Sudaryono. 2016. Manajemen Pemasaran. Andi Offset, Yogyakarta.

-----------. 2017. Metodologi Penelitian. Rajawali Pers, Jakarta.

Sugiarman, Nurmalina, Rita dan Kirbrandoko. 2015. Analisis Pengaruh Kualitas Produk dan Layanan Pelanggan terhadap Kepuasan dan Loyalitas Pest Control Operator pada PT Bayer Indonesia. Widyariset 18 (1): 1-11.

Sujarweni, V. Wiratna. 2014. Metodologi Penelitian. Pustaka Baru Press, Yogyakarta.

Sunyoto, Danang. 2012. Dasar-dasar Manajemen Pemasaran. CAPS, Yogyakarta.

Tjiptono, Fandy. 2014. Manajemen Pemasaran Jasa. Andi, Yogyakarta. 


\section{Buletin Ekonomi}

Umar, Husein. 2014. Faktor-faktor yang Mempengaruhi Loyalitas Pelanggan pada Penerbangan Low Cost Carrier. Jurnal Manajemen Transportasi dan Logistik 1 (2): 127-137.

Yamin, Sofyan. 2014. Rahasia Olah Data Lisrel. Mitra Wacana Media, Jakarta. 